\title{
Os petistas e a crise do socialismo real: os desafios da renovação e as heranças das esquerdas tradicionais
}

Izabel Cristina Gomes da Costa*

Resumo: $\mathrm{O}$ artigo analisa alguns aspectos do debate petista sobre a crise do socialismo real. Investiga a incidência do colapso daquela experiência sobre as visões de socialismo no PT. O texto também aborda o diálogo e o confronto entre as heranças da II e da III Internacional e o socialismo petista - que fazia da ideia do marco žero, da construção de um novo socialismo, desapegado das tradições - a marca de nascença do seu projeto alternativo de sociedade.

Palavras-chave: PT. Socialismo. Crise. Marco Zero.

\section{Introdução}

1991. Após vinte e um anos do colapso da primeira experiência socialista do planeta, é importante refletir sobre o debate estabelecido no seio das esquerdas brasileiras, num momento em que o país também vivia uma grave crise governamental e de projetos políticos. Envolvidas na construção de uma proposta alternativa para o país, esse campo precisou repensar com urgência os seus principais pressupostos em meio à eclosão do bloco comunista. Como as esquerdas brasileiras comportaram-se? Este artigo apresenta as discussões desenvolvidas no interior do petismo, na época, consolidando-se como o principal partido de esquerda do Brasil.

\footnotetext{
* Prof ${ }^{a}$ de História da UCAM. Doutora em História pela UFF. Pós-doutoranda no CPDOC-FGV. E-mail: izacris68@oi.com.br.
} 


\section{O PT e o mito do novo: remido de todos os pecados?}

Uma novidade irrompia no cenário político brasileiro no final da década de setenta: o movimento pela formação de um partido de trabalhadores, impulsionado pelas múltiplas mobilizações ocorridas no país, especialmente aquelas desenvolvidas pelo setor operário do ABC paulista. Para socialistas de diversas origens, o cenário prenunciava promessas de projetos revolucionários para os trabalhadores do Brasil: a crise de uma ditadura, o protagonismo e a ascensão dos movimentos sociais, lideranças advindas das mesmas e a criação de um partido de dentro da classe. Essa era a origem do PT cujo embrião desvelava importantes signos que suscitavam expectativas de uma renovação radical em relação às tradições das esquerdas. Às massas, delegava-se a tarefa de conduzir o seu próprio destino.

Todavia, as representações que explicavam os fundamentos do PT estavam envoltas em mitos que davam sentido ao seu surgimento. A ideia do "novo" e do "marco zero" na história dos trabalhadores sustentava as convicções de que o partido estava livre do DNA das esquerdas tradicionais. Ele mesmo inventaria as suas tradições. No Brasil nascia, enfim, o partido prometido da revolução, construído e dirigido pelo proletariado e não por uma "vanguarda de fora da classe". Tecendo duras críticas às múltiplas heranças das esquerdas nacionais, o imaginário político petista determinava um novo marco temporal da história da luta operária e social no Brasil: antes e depois das grandes mobilizações de 78 e $79^{1}$. O tempo anterior estava marcado por um movimento manipulado pelo "populismo". Para muitos personagens que construíam ou simpatizavam com o projeto petista, o lugar do trabalhismo era o "lixo da história". Ele representava a "manipulação", a "demagogia" e o "fisiologismo" que tão acentuadamente demarcavam a história do país.

Por outro lado, rompia-se também com a herança comunista - espaço da ortodoxia, do aparelhismo, da ausência de democracia interna. Uma história permeada por equívocos e contradições. Essa era uma marca tão forte que, para muitos militantes, tratava-se de 
um partido anticomunista. E suscitava temores entre aqueles que, antigos membros das esquerdas brasileiras, desejavam construir uma agremiação com tamanha simbologia.

Um paradoxo instalava-se: certamente não era uma agremiação comunista, mas como ser anticomunista, reunindo desde o início de sua formação uma miríade dos mais variados matizes? Estavam em jogo as heranças com as quais pretendia partilhar, imbricar a sua gênese. Se o próprio partido inventaria as suas tradições, ele mesmo teceria o seu socialismo: “[...] o socialismo que nós queremos não está escrito ainda na cartilha de nenhuma corrente, de nenhum partido político. Está na ação extraordinária de todos no debate sobre o socialismo"2.

Assim o PT nascia, com grandes imprecisões sobre o seu projeto alternativo de sociedade. Transformando em virtude o que poderia ser um defeito, procurava fugir de outra tradição das esquerdas: os rachas infindáveis, muitas vezes em torno de questões pontuais. Convivendo no interior do partido com uma pluralidade de visões, tais indefinições demarcavam as discussões a respeito das origens socialistas do petismo.

O socialismo petista ganhou maiores definições no $\mathrm{V}$ e no VII Encontro Nacional, em 1987 e 1990. Este projeto tornava-se o objetivo estratégico do PT. Num contexto internacional delimitado pelas avassaladoras mudanças no antigo monólito, sob a liderança carismática de Mikhail Gorbatchev a partir de 1985, as resoluções refletiram o debate aberto no campo das esquerdas: a questão da democracia, o modelo soviético, a fusão entre partido e Estado, as críticas à estatização generalizada, dentre outros assuntos. Mas também afirmaram com maior nitidez o compromisso com a proposta socialista. No V Encontro, a relação intrínseca entre socialismo e democracia também ocupava um lugar central no desenvolvimento da estratégia petista. O texto defendia ainda a inexistência de uma contraposição entre reforma e revolução, e a necessidade de integrar ao projeto transformador outros segmentos sociais, como os microempresários e os assalariados do mundo não fabril.

Em 1990, o VII Encontro Nacional aprofundava o acúmulo adquirido pelo partido: "Com o sentido geral de nossa política democrático e anticapitalista - perfeitamente assegurado, optamos pela construção progressiva de nossa utopia concreta, isto é da 
sociedade socialista pela qual lutamos" 3 . Associadas às formulações do $\mathrm{V}$ Encontro, as resoluções apresentavam críticas mais nítidas ao modelo da social-democracia e também à perspectiva do socialismo real, incompatível com o projeto petista. Assim, o partido reafirmava o pluralismo ideológico, negando a sua filiação a qualquer filosofia oficial.

Diante do fracasso do socialismo real, o PT identificava aspectos positivos na crise que poderiam renovar a democracia socialista. Tais movimentos deveriam ser valorizados, apesar das suas inúmeras contradições e da hegemonia de forças reacionárias favoráveis à regressão capitalista. Eles rompiam com a paralisia política, recolocando em cena novos agentes políticos e sociais.

O I Congresso do Partido dos Trabalhadores, no ano de 1991, tornou-se o lugar, por excelência, das principais discussões sobre os caminhos petistas para alcançar o socialismo. O evento envolveu uma miríade de militantes e tendências através da realização de inúmeros debates, da formulação de vários textos e da publicação de cadernos de teses que circularam durante os encontros preparatórios.

A polêmica existente nos primeiros anos de criação do PT reaparecia, com outras tonalidades, no processo congressual, decorridos onze anos da sua fundação: era central ou não para o partido reafirmar a sua visão estratégica em direção ao socialismo? Determinadas lideranças partidárias, como o dirigente da Articulação, tendência majoritária do PT, José Luís Fevereiro, identificavam no I Congresso a imposição de uma "polarização doutrinária”, reduzindo o debate a uma dicotomia superficialmente construída pelos setores "órfãos ou herdeiros do leninismo mais ortodoxo"4. Logo, a agremiação havia perdido a oportunidade de avançar na sua estratégia de conquista do governo federal. Para muitos, a perplexidade instalava-se porque aquela arenga era "estranha à tradição majoritária do PT". O partido continuava não tendo nada a ver com aquilo.

Em pleno ano de 1991, com os vários muros caindo, as esquerdas atônitas e as direitas em franca ofensiva, como negar a centralidade do assunto nos debates congressuais? Para um partido que se denominava socialista, como separar as suas orientações mais imediatas de um profundo balanço sobre a trajetória traçada por aquelas experiências alternativas no decorrer do século XX? 
Apesar das resistências, Teoria e Debate ${ }^{5}$ a partir de dezembro de 1989, dava o pontapé inicial nas discussões. Reivindicando a abertura do debate, confirmada pelo VII Encontro Nacional, a revista tornava-se o principal espaço de reflexão sobre os "caminhos estratégicos" para a transformação socialista do Brasil. Dessa forma, o texto de abertura alertava sobre a centralidade destes questionamentos. Eles atingiam diretamente o partido e se relacionavam ao futuro da utopia socialista no país:

Não nos iludamos: a fábula que se conta hoje no mundo socialista diz respeito a nós. O que está em jogo é nada mais nada menos que o futuro de nosso projeto político de construir no Brasil um socialismo democrático. Se não decifrarmos esta esfinge em tempo, ela certamente nos devorará. Pior é que, a rigor, mesmo que a decifremos, talvez não estejamos em condições de escapar ao tipo de crise que ronda hoje a experiência socialista. Mas pelo menos estaremos mais bem preparados para enfrentá-la, quando chegar - se chegar - a nossa hora ${ }^{6}$.

O Partido dos Trabalhadores encontrava-se, então, diante da necessidade de exprimir de forma mais concreta o que era o tal do socialismo petista. As definições vagas - "Nem socialismo real nem social-democracia" - demonstravam-se insuficientes para os seus desafios. Instaurar um profundo balanço sobre as heranças compartilhadas pelas esquerdas e traçar novas perspectivas para o socialismo no final do século XX tornavam-se possibilidades através das quais o partido poderia sobreviver aos vendavais, sofrendo as menores avarias possíveis, dotando-o de condições de responder às crises e de propor alternativas nos tempos mais difíceis. 


\section{Em nome de Marx: os marxismos e as experiências socialistas do século $\mathrm{XX}$}

Avaliando a realização dos prognósticos marxistas nas primeiras experiências socialistas do século XX, um tema impunha-se: a tomada do poder. Mapeando os processos revolucionários ocorridos a partir de 1917, o debate proposto pelo petista Daniel Aarão Reis questionava a base socialista dessas insurreições após a derrota das suas antigas classes dominantes, desconstituindo a clássica visão de que tais processos se tornaram vitoriosos sob essa bandeira. Assim como a Revolução Russa, esses movimentos foram compostos por uma multiplicidade de projetos que congregou, num determinado momento, distintos objetivos: a libertação nacional, a questão agrária, a luta antiditatorial, a paz, as melhores condições de trabalho, os diversos socialismos ${ }^{7}$.

Aldo Fornazieri também reexaminava a questão do poder. Nas sociedades contemporâneas, a estratégia rupturista bolchevique era inoperante e estava ultrapassada. Haveria uma relação de interdependência, na qual o poder se apresentava como resultado de uma relação em que o subalterno dispõe sempre da possibilidade de recusa dos resultados seletivos do poderoso ${ }^{8}$. Portanto, o principal fator de poder localizava-se na obtenção da hegemonia, e não na violência física. Disputá-lo significava criar alternativas para os dominados, afirmando a sua autonomia no processo seletivo.

Para Marco Aurélio Garcia, a visão petista sobre o poder não devia limitar-se às duas tradições clássicas dos movimentos das esquerdas: "[...] um dos avanços do PT é abandonar a ideia do poder como um lugar a ser tomado e reformado (proposta social-democrata) ou tomado, destruído e reconstruído (proposta revolucionária clássica)" .

No campo das correntes "marxistas revolucionárias" encontravam-se as definições clássicas sobre os processos revolucionários do século XX. Revoluções socialistas na sua essência, elas lideraram uma miríade de mobilizações. Observavam-se, assim, traços característicos, apesar da existência de várias estratégias.

Golpe ou revolução? Entrelaçado à questão da tomada do poder estava o caráter da revolução russa. Jacob Gorender defendia o fundamento do outubro russo. Para ele nem todos os golpes 
de Estado seriam necessariamente reacionários. No caso da Rússia, sob a vigência de um duplo poder, ele precisava ser compreendido como uma resposta às negativas do governo provisório em atender as reivindicações dos sovietes, já conquistados pela maioria bolchevique. Portanto, "[...] o que começou sob a forma de um golpe de Estado, constituía, na verdade, a mais profunda revolução dos tempos modernos. Revolução que precisou ser assegurada por meio da guerra civil travada de 1918 a $1921 " 10$.

Nos embates da história, esta é uma das polêmicas mais importantes a respeito do balanço das revoluções do século XX. Até que ponto tais processos não expressaram o programa e as estratégias de um partido que, entendendo-se como portador da verdade revolucionária, impôs a sua dinâmica ao conjunto da sociedade? É indubitável o caráter revolucionário do movimento russo de 1917. A força da ação dos bolcheviques em outubro originou-se das múltiplas mobilizações em curso no império. Essas não identificaram o reconhecimento das suas reivindicações nos governos estabelecidos após fevereiro. Por um lado, então, a vitória da insurreição liderada por Lênin deveu-se ao atendimento imediato das exigências de tais movimentos sociais. Entretanto, a opção efetivada pelos bolcheviques - alvo de tensas discordâncias no interior da própria organização - desvelou a concepção que conferia ao partido e à sua vanguarda a supremacia sobre os sovietes: único partido da classe, portador da verdade revolucionária, e, portanto, autorizado a exercer o poder em nome dos trabalhadores e sobre os mesmos.

Outras interpretações, como a de Marc Ferro, demarcam o caráter autoritário da insurreição de outubro de 1917. E autoritário porque a decisão quanto ao desencadeamento da sublevação coube, exclusivamente, ao partido bolchevique. Ao passar por cima das forças vivas mais importantes do processo revolucionário russo, ele golpeara não apenas o governo provisório, mas, principalmente, os poderes da organização soviética. Apesar da insígnia "todo poder aos sovietes", a partir deste evento, as decisões concentraram-se cada vez mais nas mãos do partido, evoluindo para uma ditadura de partido único.

Outra questão também se colocava: compreender a lógica de tais organizações populares significava descobrir nelas uma pluralidade de processos ativados pelo movimento revolucionário de 17. A 
dicotomia estabelecida pela teoria do duplo poder escondia a grande heterogeneidade existente no seu interior: operários, camponeses, vários segmentos sociais das nacionalidades, anarquistas, socialistas revolucionários... Enfim, os sovietes expressavam, eles mesmos, uma multiplicidade de poderes que não desaguavam necessariamente nas concepções e no comando do partido bolchevique.

\section{Renovação ou restauração?}

\section{As visões da crise no bloco soviético}

As visões diferenciadas, muitas vezes dicotômicas, que conviviam no PT, possuíam pontos em comum quando o assunto era a caracterização do Estado soviético. Muitos reivindicavam o processo revolucionário ocorrido em 1917. Mas, por caminhos distintos, grande parte das correntes e dos militantes petistas defendia a inexistência do socialismo na URSS, e, por consequência, nos demais países do bloco comunista. A exceção ficava por conta do caso cubano e do pouquíssimo conhecido enigma chinês.

Os países do chamado socialismo real recebiam muitas denominações que tentavam destacar algum aspecto deste modelo: ditaduras burocráticas, estados pós-capitalistas, estados operários degenerados ou deformados, sociedades pós-revolucionárias, dentre outras nomenclaturas. Geralmente os militantes petistas encontravam dificuldades para fixar como socialistas as formações econômico-sociais existentes, fruto de revoluções sociais ou da ocupação do Exército Vermelho após a II guerra mundial. O socialismo deveria ser inerentemente democrático, tornando inconcebível a existência de uma matriz de tipo autoritário. Refugar esta ideia levava à reprodução de um pressuposto comum: a visão de um verdadeiro marxismo, puro, nunca implementado ou do qual tais processos haviam se desviado ${ }^{11}$.

Por outro viés, assinalando o antissovietismo presente nos debates sobre os setenta anos da revolução russa, vários comunistas da geração pré-64, como Jacob Gorender, também identificavam a URSS como um Estado socialista, apesar das sérias deformações existentes no país ${ }^{12}$. 
Entre aqueles que elaboravam uma crítica radical ao legado da III Internacional, também não era um ponto pacífico a definição da natureza de tais países. Para Augusto de Franco, eles representavam um "socialismo realmente inexistente". E refutava a matriz da "teoria da degeneração" - a existência de uma fase socialista na revolução russa, posteriormente burocratizada e degenerada ${ }^{13}$.

Maurício Tragtenberg estabelecia o fim do sonho socialista de outubro de dezessete a partir do ano de 1920. Sob Stálin, emergira na URSS um Estado burocrático e policial. Assim, o socialismo não havia sido derrotado "[...] porque sequer existiu nessas regiões"14. Adquirindo a forma de uma elite industrializante que procurou construir o chamado "socialismo em um só país", a crise na URSS e no Leste confirmava as antevisões dos clássicos do marxismo sobre a impossibilidade desta tese, uma concepção bastante comum à maioria das correntes petistas. A diferença situava-se nas avaliações sobre o momento da degeneração. Para alguns o massacre de Kronstradt, uma insurreição de marinheiros e anarquistas severamente reprimida sob o comando de Lênin e de Trotsky. Para outros a ilegalidade das demais organizações e a proibição de frações no interior do partido bolchevique. Os trotsquistas delimitavam o final dos anos vinte como o marco da vitória da contrarrevolução burocrática; ou seja, após a morte de Lênin e da derrota de Trotsky na disputa dentro do PCUS.

Em vez de pós-capitalistas, sociedades burocráticas pré-capitalistas. Defendendo esta visão, Vladimir Palmeira afirmava que os soviéticos, diante do fracasso de uma possível revolução europeia, levaram adiante somente um processo de independência nacional e de industrialização:

Com o pós-guerra e os novos padrões de divisão internacional do trabalho dos anos 60/70, as primeiras nuvens. Estas economias perdem ritmo e mostram seu caráter duplamente conservador: são incapazes de superar o modelo industrial de produção herdado do capitalismo, são incapazes de reproduzir internamente o dinamismo tecnológico do capitalismo ${ }^{15}$. 
A partir de 1985, o "fenômeno Gorbatchev" modificava o cenário internacional. As reformas em curso na URSS suscitavam grandes interesses e muitas dúvidas. Jamais indiferença. Havia o incentivo da cobertura da mídia ocidental, primeiramente temendo um novo fôlego do socialismo; depois apostando no sentido pró-capitalista das transformações. As autoridades soviéticas também realizavam uma verdadeira ofensiva midiática para reformar o país e a sua imagem no mundo. No meio do turbilhão, as esquerdas encontravam-se perplexas. Atônitas, elas tinham enormes dificuldades para caracterizar as mudanças no antigo monólito.

Perestroika e Glasnost: "Duas palavras de (des)ordem”. Assim, Teoria e Debate anunciava, em seu primeiro número, as suas percepções sobre o tema. Para os "velhos burocratas soviéticos", um incômodo. Para os "críticos mais ferozes", apenas um truque de marketing. Mas a T\&D recebia a notícia como "algo de novo na União Soviética", "um fator de esperança". Reivindicando os setenta anos da revolução russa, a publicação concordava com o líder da URSS e identificava na burocratização um grande obstáculo ${ }^{16}$.

No número seguinte, o debate continuava com as impressões de David Capistrano Filho e Luís Favre ${ }^{17}$. O primeiro ressaltava o imenso significado político da Perestroika e da Glasnost. O sucesso de Gorbatchev ratificava a superioridade do sistema diante da propaganda burguesa sobre o fracasso do socialismo. Quanto às reformas, a necessidade de um caráter democrático, mesmo que elas não pudessem ser avaliadas por "modelos abstratos". Talvez o pluripartidarismo continuasse improvável, pois as mudanças ocorriam através do partido e do Estado. Capistrano não acreditava na hipótese "das reformas abrirem caminho ao desenvolvimento do capitalismo" devido à liquidação da burguesia naquele país, à cultura socialista enraizada nos trabalhadores e à sua consciência quanto à superioridade do sistema. Setenta anos após a vitória do "outubro vermelho" discutia-se o futuro do socialismo na União Soviética.

Luís Favre comparava a repercussão das reformas na URSS ao fenômeno da "desestalinização" da época de Kruchev, assumindo um impacto ainda maior. Elaborando avaliações mais cautelosas, para ele, a reversão do quadro de declínio econômico não era possível sem a modificação das relações políticas estabelecidas 
entre o poder e a sociedade. Grandes resistências tornavam-se um obstáculo ao projeto de Gorbatchev. Havia divergências na nomenclatura ${ }^{18}$ dominante quanto à associação entre a URSS e os países imperialistas - cujo acordo não questionaria a dominação do mercado mundial pelo imperialismo. Da mesma forma, o cerne da associação com o capital misto - liberdade de repartição de lucros, mão de obra barata e estabilidade política - também gerava problemas entre os trabalhadores e no interior do próprio aparelho burocrático. No plano internacional, a colaboração com os EUA e as concessões da URSS para uma distensão "mutuamente benéfica" também provocariam crises no bloco socialista.

$\mathrm{Na}$ visão do petista, o PT deveria apoiar todas as medidas de democratização como ponto de partida para reforçar a luta para acabar com a burocracia stalinista. Porém muitos caminhos estavam em disputa. Para numerosos militantes, as medidas representavam a correção dos erros do socialismo pelos dirigentes do PCUS, possibilitando a sua defesa por aqueles que haviam rompido com os PCs.

Principais defensores da tese da revolução política, as correntes trotsquistas (IV Internacional) possuíam uma visão muito particular do processo. Baseando-se nas concepções do revolucionário russo Leon Trotsky, definiam a URSS como um estado operário degenerado, congelado na transição do capitalismo para o socialismo. Com a estrutura econômica estatizada, esses países eram dirigidos por uma casta burocrática, instalada no poder desde os anos trinta, marco da vitória da contrarrevolução. Os prognósticos indicavam a emergência de uma crise, de crescentes mobilizações de massas que realizariam uma insurreição na URSS, liquidando os setores da burocracia. Assim, a implantação do socialismo democrático devolveria o poder político para as mãos dos trabalhadores. Para a Democracia Socialista (tendência associada ao Secretariado Unificado, um dos vários organismos autodenominado IV Internacional), os acontecimentos de 1989 confirmavam o início da revolução política. Tal como havia ocorrido antes na Hungria, Tchecoslováquia e Polônia, aquele processo alcançava uma escala mais ampla, visto que envolvia também a URSS. Dessa forma, a retomada da construção do socialismo, em curto prazo, deixava de ser uma hipótese ${ }^{19}$. 
Mas as avaliações sobre o "fenômeno Gorbatchev" variavam. A DS separava o conteúdo da Perestroika e da Glasnost, vislumbrando nesta última alguns aspectos progressivos, além da necessidade do seu aprofundamento. Criticando essa visão - qualificada como um "apoio crítico" e uma "regressão política do Programa" (da IV Internacional) -, a Convergência Socialista (agrupamento afiliado à Liga Internacionalista dos Trabalhadores, e também fundadora do atual PSTU), condenava o conjunto das mudanças em curso naquele país. Se o secretário-geral era "o principal sócio de Bush para uma restauração capitalista da URSS", as reformas, desde o início, visavam a esse objetivo, estabelecido num jogo previsto de comum acordo com os EUA. Todos os setores do PCUS seriam, no mínimo, cúmplices daquelas medidas ${ }^{20}$. Valério Arcary, dirigente da tendência, observava um papel secundário da Glasnost em relação às mobilizações populares no país. Tais concessões democráticas direcionavam-se, fundamentalmente, para os setores da própria burocracia, atrasando o processo de implosão das mil frações que existiam dentro do partido soviético. As massas estavam impondo na lei aquilo que já haviam conquistado na prática.

As análises das correntes trotsquistas, permeadas pelas esperanças de confirmação dos seus prognósticos, expressavam um sentimento ufanista em relação à realidade, apesar da incontestável ofensiva liberal. As gradações existiam, todavia as mesmas compreendiam a crise do Leste como o fim das amarras e a liberação de promissoras perspectivas para a utopia socialista.

A Convergência Socialista não admitia como uma possibilidade concreta a restauração capitalista ou o descenso na conjuntura internacional. Impressionada com a magnitude das mobilizações, ela afirmava, em tom categórico, que a crise na URSS havia aberto uma nova etapa, um novo "giro histórico". Com a vitória da revolução política, "novos outubros" estariam na ordem do dia: “[...] nunca o Leste foi tão favorável ao socialismo! Porque as massas estão em movimento, e um elemento fundamental da ideologia marxista é acreditar profundamente que a emancipação dos trabalhadores será obra dos próprios trabalhadores"21.

As enormes expectativas da CS refletiam-se no documento interno de 1990. A nova etapa mundial, aberta a partir de 1989, demarcava-se pela impossibilidade de retrocesso da revolução política, pelo 
aprofundamento do ascenso revolucionário no coração da Europa capitalista e pela sua penetração nos EUA e no Japão. O pêndulo pendia para o lado da revolução ${ }^{22}$.

Para o petista Wilson Muller, a interpretação do trotsquismo sobre os acontecimentos do Leste Europeu decorria de uma série de pressupostos existentes no "marxismo ortodoxo": a existência de uma consciência socialista imanente entre os trabalhadores, a desconsideração do apoio da sociedade civil às ditaduras burocráticas e a análise centrada quase que exclusivamente no Estado ${ }^{23}$.

Imbuídos ou não dos mesmos referenciais, a teoria da confusão tornava-se um elemento central para explicar porque as populações do leste europeu apoiavam decisivamente a restauração das economias de mercado em seus países. Ao libertarem-se das amarras da burocracia, aqueles trabalhadores não cumpriam a sua missão histórica de realizar o socialismo com democracia. Pelo contrário, votavam em partidos restauradores, defendendo o retorno do modelo liberal e dos valores do mundo burguês. A confusão e as ilusões dos trabalhadores com o atraente capitalismo avançado abriam caminho para a contrarrevolução. Desvirtuavam o processo. Desfaziam a promessa.

Segundo Muller, o "pior cego" não queria ver que as supostas reivindicações de esquerda de tais movimentos - democracia e condenação dos privilégios - não significavam necessariamente o engajamento na luta pelo socialismo democrático. O caso alemão era exemplar: o Novo Fórum havia sido derrotado fragorosamente nas eleições por vários partidos pró-capitalistas que ganharam o apoio das massas empunhando essas bandeiras e capitalizando seus sentimentos ${ }^{24}$.

O chamado caráter objetivo dessas sublevações também se tornava uma ideia-força quase irresistível. A primeira ação das massas - objetiva, concreta, mesmo sem consciência - era favorável ao socialismo. A ofensiva da propaganda capitalista e das direções burocráticas e/ou traidoras desviava o rumo das massas, instalando o elemento da confusão.

1991. O golpe de agosto na União Soviética selava bem mais do que a sôfrega tentativa de setores do Partido Comunista para se manterem no poder. $\mathrm{O}$ mundo chegava ao fim de um ciclo aberto 
com a revolução russa de 1917 e fechado com o desaparecimento da primeira experiência socialista do planeta. Teoria e Debate concedia a palavra a Jacob Gorender. Uma "Testemunha Ocular"25 do putsch, ele diagnosticava a evolução da sociedade soviética após os acontecimentos de 1985. A grande influência de um capitalismo desenvolvido próspero e a ausência de uma experiência alternativa de socialismo democrático definiam um sentido ideológico pró-capitalista. O marxismo e o comunismo tornavam-se alvos da aversão e da hostilidade de grande parte da população. Muitos cidadãos da URSS reivindicavam apenas a revolução de fevereiro de 1917, condenando a insurreição de outubro como a responsável pelo retardo do país.

Numa outra perspectiva, a Convergência Socialista procedia a uma leitura muito particular dos eventos de agosto: o putsch na URSS acontecia contra a revolução política em curso naquele país. Assim como Yeltsin e Gorbatchev, os golpistas, liderados pelo vice-presidente Ianaiev, também possuíam a sua versão da economia de mercado. As edições eram avassaladoras: na capa do jornal, o título: Revolução Derruba Ditadura Stalinista. As imagens eram inequívocas: a população ocupava a praça pública. Agitava as bandeiras. Em cima dos tanques, tomava o poder em suas mãos. Quaisquer semelhanças com as fotografias de outubro de 1917 não eram meras coincidências. Numa outra edição, um soldado tremulava uma bandeira vermelha em frente à multidão ${ }^{26}$. Irresistível. Enfim, o triunfo da revolução política? O prometido socialismo democrático?

Homens e mulheres, de carne e osso, deveriam encarnar aquele projeto. Quem na URSS representava o referido ideal? Para a Convergência Socialista eram elementos objetivos e inconscientes. Apesar das várias candidaturas para o preenchimento da vaga aberta - de direção socialista e revolucionária - nenhum daqueles grupos defendia um projeto de socialismo democrático. Quando ultrapassavam os limites das reivindicações democráticas e antiburocráticas, afirmavam propostas que eram vistas pela organização como capitulacionistas ou restauradoras.

A CS discordava do que a realidade demonstrava. Se existiam ainda dúvidas, o golpe de agosto selava o destino do socialismo. Este encarnava-se nos setores golpistas. E, para os milhões de 
proletários soviéticos, a maior de todas as utopias do século XX emitia esses sentidos: burocrática, antidemocrática e conservadora. Assim, a derrota do putsch não fortalecia a revolução política. Pelo contrário, Yelstin irrompia a cena com incrível robustez. A imagem de herói da resistência, veiculada pela mídia nos quatro cantos do planeta, favorecia e apressava a restauração capitalista. Aos socialistas, o silêncio. Aos comunistas, a caçada. Fechamento do PCUS, prisões e condenação para os seus afiliados. Sem exceção.

Contradizendo as idílicas imagens, vários dirigentes políticos e historiadores relativizaram a intensidade da mobilização. Ressaltaram uma forte apatia e o pouco envolvimento do conjunto da população por toda a URSS. O jornal Em Tempo, publicado pela DS, também apresentava versões que ratificavam a análise alternativa. O dirigente internacional da tendência petista, David Seppo, enfatizava a fraca mobilização popular e a espetacularização do evento pela imprensa ocidental. Ao contrário do discurso midiático, a rápida derrota devia-se mais à "fraqueza política e às divisões internas dos conspiradores" do que à "resistência popular ou à firmeza de Yeltsin"27.

As transformações do inesquecível ano de 1991 selavam definitivamente o destino, pelo menos provisório, das esquerdas: elas mergulhavam numa trajetória defensiva. Necessitavam começar tudo de novo. E refazer a utopia socialista. Entretanto, as profundas mudanças não decretavam o "fim da história". O mundo estava marcado por muitas situações de instabilidade que antecipavam a ocorrência de movimentos sociais pelo planeta. Sem compartilhar das análises catastrofistas, Marco Aurélio Garcia observava um capitalismo com grandes dificuldades econômicas, traduzidas no plano social pelo desemprego, pela pobreza, pelas migrações incontroláveis, pela marginalização, pela destruição do meio ambiente, pelos movimentos racistas, pelas xenofobias e pelos fundamentalismos religiosos. A atualidade do socialismo, de uma perspectiva anticapitalista ou pós-capitalista, relacionava-se diretamente aos desdobramentos concretos do "capitalismo realmente existente" em escala mundial ${ }^{28}$. 


\section{Considerações finais: um passo à frente na construção do socialismo?}

O PT talvez tenha sido um dos pouquíssimos partidos das esquerdas mundiais que conseguiu sobreviver à débâcle do socialismo real e passar pelos anos mais duros da ofensiva liberal sem sofrer enormes divisões ou o definhamento da sua base de apoio. Pelo contrário, ele cresceu durante toda a década de noventa.

Mas uma pergunta se coloca: apesar das importantes vitórias em pleno auge do neoliberalismo e do seu crescimento praticamente ininterrupto, o Partido dos Trabalhadores conseguiu preparar-se para enfrentar a crise do socialismo? Ou ele cedeu à ilusão de que a fábula contada não lhe dizia respeito?

A fase era conservadora e defensiva. A conjuntura indicava grandes dificuldades. Contraditoriamente, a situação mundial, em especial da América Latina, tornava-se a expressão mais viva de que a história não havia chegado ao seu fim. O socialismo continuava atual diante das instabilidades e barbáries criadas pelo "capitalismo realmente existente". Todavia, tal qual se encontravam, as esquerdas não seriam capazes de responder aos novos tempos. Havia a necessidade de uma profunda recomposição do projeto socialista, resgatando e reconstruindo o espaço publico "com a consequente reabilitação da política como atividade transformadora e instrumento de libertação de homens e mulheres"29.

Dessa forma o debate e as definições efetivas do Partido dos Trabalhadores acerca do socialismo, dos marxismos e das estratégias revolucionárias aconteceram em meio à mais grave crise das esquerdas mundiais. Este aspecto proporcionou um impacto decisivo sobre o desenvolvimento do seu projeto socialista. Do final do século XIX até as últimas décadas do século XX, a maioria das organizações do campo político das esquerdas formou e amadureceu as suas convicções numa época na qual o socialismo era uma referência essencial para aqueles que, partidários do modelo socialdemocrata ou comunista, almejavam mudar o mundo. Apesar dos terríveis períodos pelos quais passara o planeta, sabia-se pelo que lutar. E morria-se por esses ideais. Não foi bem assim com o PT. Certamente, o impacto da derrota dos EUA no Vietnã, a luta 
contra as ditaduras pelo mundo afora e a forte atração de revoluções como a nicaraguense reacenderam os ânimos das utopias revolucionárias. Mas, desde a sua fundação, o movimento socialista internacional encontrava-se envolvido numa profunda crise: entre os comunistas, desde a morte de Stálin, os descaminhos do socialismo de tipo soviético. $\mathrm{Na}$ social-democracia europeia, as dificuldades diante das experiências de governo, como o caso do Partido Socialista Francês, e das profundas transformações no sistema produtivo do capitalismo central.

A origem socialista do Partido dos Trabalhadores sempre suscitou significativas controvérsias. Mesmo que a proposta não tenha sido claramente incorporada no início da sua formação, desde cedo, a agremiação confrontou-se com essa questão. O pensamento socialista, presente em seu interior, era forte demais para que fosse apenas uma expressão marginal. Ele perpassava não apenas as correntes marxistas-leninistas e os militantes oriundos da luta armada, mas também vários adeptos da Igreja Católica, identificados com a Teologia da Libertação, intelectuais e algumas lideranças do movimento sindical. O partido nascia, crescia e elaborava afirmações distintas sobre o seu próprio socialismo: "nem socialismo real nem social-democracia". Essa palavra de ordem sintetizava o compromisso com o projeto de transformação, mas, sobretudo, o desejo de construir uma outra alternativa aos dois polos tradicionais das esquerdas.

O mito do novo influenciava diretamente as elaborações do socialismo petista. Distinguia-se a visão espontaneísta de que todas as respostas se originavam da experiência concreta. Era o momento da práxis. Apreendida, muitas vezes, apenas como a expressão das práticas cotidianas, desprezava-se uma outra dimensão que deveria ser indissociável, a da teoria. Se havia a reprodução de um messianismo operário, existia também um messianismo popular. A sapiência do povo bastava para o amadurecimento dos caminhos socialistas do PT. Mas, apesar da grande força explosiva de tais movimentos, emergidos da ditadura civil-militar no final dos anos setenta, eles careciam de um maior acúmulo, fruto de um contexto histórico nacional demarcado pelo autoritarismo e pela frágil organização popular, em que a experiência democrática havia perdurado apenas dezenove anos. 
Os petistas e a crise do socialismo real:...

Num sentido negativo, permanecia latente no Partido dos Trabalhadores a tendência à rejeição das heranças pregressas. De fato, a discussão interna havia sido intensa, mas faltava encontrar o PT dentro daquele debate. De que forma as tradições comunistas, social-democratas, trabalhistas, anarquistas influenciavam o pensamento e a ação petista? Como os descaminhos, já perceptíveis, na gestão das prefeituras, na relação com os movimentos sociais e com os aparatos sindicais expressavam os impasses históricos das experiências socialistas? Concordando com Alexandre Fortes, essa repulsa teve como principal efeito "[...] alimentar a ignorância em relação à história e à ideia, fundamentalista e prepotente [...]”, de que o partido detinha a política correta e de que o seu futuro estava garantido (FORTES, 2005, p. 201). E isto parecia verdadeiro. Em meio ao turbilhão, o PT crescia. Politicamente, consolidando-se como uma das principais alternativas das esquerdas em âmbito internacional. Eleitoralmente e numericamente, conquistando personalidades e postos estratégicos na institucionalidade.

Em relação às interpretações petistas acerca das sociedades do leste europeu e da crise do socialismo real, predominavam aquelas que negavam a sua natureza socialista, destacando-se as leituras centradas na tese da burocratização e da degeneração. Tendo como principal referência as avaliações do revolucionário russo Leon Trotsky, a concepção defendia a insustentabilidade do desenvolvimento do socialismo nos marcos nacionais. Ao não ocorrer revoluções sociais nos países capitalistas avançados, a revolução russa estava condenada ao isolamento internacional e à emergência de alguma forma de deformação burocrática. A causa fundamental daquele processo localizava-se na corruptela originada dentro do próprio Partido Comunista. Mesmo assim, Trotsky destacava o papel contraditório da burocracia soviética: internamente, ela ainda assumia um papel progressista. Externamente, porém, adquiria um perfil abertamente contrarrevolucionário através da política de boa vizinhança com o imperialismo.

O cientista político Luís Fernandes identifica importantes problemas no estabelecimento da degeneração como uma decorrência do isolamento internacional e de uma revolução numa sociedade atrasada. Se assim o fosse, por que a crise de 1989 não democratizou aquele poder político, mas encaminhou-se para o 
desmantelamento do regime? Segundo o autor, é possível que a autonomização daquele poder tenha se originado de características estruturais do próprio socialismo. Além disso, ele também aponta uma grande inconsistência na identificação dos grupos que compunham a "casta burocrática". Se o poder estatal-partidário soviético era uma expressão da dominação da burocracia, a tese deixava sem resposta o porquê dos violentos expurgos contra o mesmo na "grande virada" de 1928 (FERNANDES, 2000, p. 85-92).

Entretanto, na busca por novas respostas para a compreensão do fenômeno, indo além da tese da degeneração do Estado soviético, vários petistas enriqueceram as suas análises com novas abordagens. Os estudos baseados na cultura política, na sociologia histórica e na história social, de autores como Eric Carr, Moshe Lewin e Alec Nove, ocuparam o plano central das análises sobre as contradições e as pressões sociais existentes na URSS.

Reconhecendo os distintos graus de apreensão, a ampla maioria dos petistas estabelecia uma crítica muito clara em relação à experiência soviética. Mesmo entre aqueles que ressaltavam as importantes conquistas do regime e reivindicavam os primeiros anos do socialismo na URSS, o balanço era negativo. Destacava-se, também, numa dinâmica crescente, uma rejeição aos desdobramentos ocorridos, principalmente, a partir de outubro de 1917.

As batalhas entre as diversas interpretações sobre as primeiras nações socialistas do planeta também envolviam as heranças dos marxismos. No campo marxista revolucionário as divergências não eram menores. Elegendo a obra de Karl Marx como o melhor método de análise das sociedades capitalistas e de construção de um projeto alternativo, um núcleo, mais ortodoxo, defendia a retomada da leitura original de Marx, Engels, Lênin, Trotsky e Rosa Luxemburgo para a sua renovação. Outras correntes advogavam a importância do influxo de novas leituras marxianas, acadêmicas ou não, e até mesmo de outras vertentes de pensamento para a elaboração de respostas condizentes aos desafios de uma realidade em profunda transformação.

As leituras reformistas - revolucionárias ou não - elaboravam questionamentos mais profundos aos marxismos. Inexistia, contudo, uma crítica homogênea. Sem desconsiderar a validade do mesmo 
Os petistas e a crise do socialismo real:...

enquanto uma teoria explicativa, elas ressaltavam muitas inadequações e a ausência de respostas às alterações do sistema capitalista no final do século XX. Portanto, a obra de Marx deveria ser modernizada e complementada à luz de novos conceitos e autores. Revisavam, por exemplo, a visão fatalista, o messianismo operário, a inevitabilidade do socialismo e a ideia de progresso presentes nos seus pressupostos. Havia também aqueles que, apesar de minoritários, evoluíram da necessidade de revisão dos marxismos para a defesa aberta do seu abandono. Muitos, formalmente, conservaram uma reverência a Marx, mas que já não possuía qualquer consequência prática para as suas formulações.

As interrogações a respeito da II Internacional também existiam. Originando-se de todos os campos do PT, elas eram expressivas. Mas faltava um balanço profundo sobre os partidos da social-democracia nos séculos XIX e XX. Um conhecimento histórico concreto sobre as experiências desenvolvidas por eles nos espaços de poder local e nos governos das suas respectivas nações. Em que medida os problemas existentes naquela via estavam presentes na tradição da III Internacional e no próprio marxismo? As demandas eram muitas para quem possuía como estratégia governar o Brasil e executar profundas transformações. Entretanto, elas se perdiam nas análises que determinavam tais experiências como traições. Dessa maneira, como discutir e avaliar alguma positividade em traiçôes? O partido, refutando ou apoiando, optava por esconder-se na definição genérica de social-democratização. Mas continuava ignorante em relação aos seus desafios e impasses. Alguns petistas tentaram colocar questões mais significativas para as heranças da II Internacional: a incorporação da democracia e da via representativa na sua estratégia de poder, as políticas de reforma do Estado e de distribuição de renda, entre outras. Mas, em geral, elas também terminavam na tese dos desvios.

Formalmente, ninguém - ou pouquíssimos - defendia o modelo da social-democracia para o Partido dos Trabalhadores. $\mathrm{Na}$ verdade, poucos aventuraram-se em tal reflexão. Se stalinismo era um termo maldito nas esquerdas, no PT, pior ainda era ser rotulado de social-democrata. Os demônios materializavam-se: sempre à espreita, esperava a hora certa para trair. Um xingamento terrível. 
Nas avaliações elaboradas pelas várias correntes e militantes do Partido dos Trabalhadores, havia um desequilíbrio entre as duas Internacionais. Os problemas do socialismo eram analisados, principalmente, sob a ótica das heranças deixadas pelo modelo comunista. $\mathrm{O}$ stalinismo ascendia à condição de principal bode expiatório das arengas petistas. A burocratização, a profissionalização de dirigentes e militantes, o crescimento cada vez mais tentacular dos aparatos partidário e sindical eram a expressão desse fenômeno. Evidentemente, a versão soviética tornou-se a expressão mais concreta de um poder socialista. Mas o modelo social-democrata, mesmo abandonando a perspectiva rupturista como o caminho para a transformação, fincara profundas marcas nas esquerdas. Assim a II Internacional saía praticamente ilesa de uma análise mais acurada sobre as suas experiências institucionais e sociais. Acossando o cachorro morto, o filho feio sem pai - como bem definem os ditados populares - o partido perdia a oportunidade de refletir sobre as razões da construção e dos descaminhos impostos pela estruturação de poderosas máquinas partidárias e sindicais - dotadas de problemas tão graves como aqueles existentes na tradição comunista - pelas esquerdas mundiais.

Em termos programáticos, o desfecho da primeira etapa da história do Partido dos Trabalhadores não significou a sua rendição à ordem burguesa com o abandono do socialismo, mas o amadurecimento de uma série de discussões abertas desde o V Encontro Nacional. Em meio às crises, perplexidades e enormes mutações verificadas no diverso campo das esquerdas mundiais - muitas vezes influenciado pelas concepções do triunfo do capitalismo e do surgimento de uma nova ordem mundial - o PT direcionou suas críticas a alguns conceitos clássicos marxianos e da tradição da III Internacional sem, contudo, aderir às teses das direitas. Contraditoriamente, a implosão do campo permitiu o desenvolvimento de novas temáticas, conceitos e autores, antes interditados ou heréticos, que contribuiu para a renovação do pensamento socialista petista. Assim, a não ser que todo o questionamento seja visto como uma mudança de lado, o PT saiu do I Congresso reafirmando o compromisso com o socialismo. 
Entretanto a arena real dos embates encontrava-se fora do partido. Na sociedade. Assim a "incorporação do PT à ordem burguesa" não acontecia devido à adoção programática das teses "social-democratas". Intolerante com a investigação analítica da realidade social e com a discussão teórica, o avanço do "pragmatismo", na maioria das vezes, destituído de qualquer viés ideológico, ditava crescentemente a dinâmica no que dizia respeito aos dilemas da ação concreta e cotidiana na institucionalidade, nos aparelhos de Estado e na máquina sindical. Eles aceitavam o desenvolvimento do debate de ordem doutrinária desde que este não interferisse nas questões práticas (REIS, 2007, p. 445). Era a resposta à impossibilidade de implantar, num curto e médio prazo, o socialismo no Brasil. Mas também era a expressão dramática das lacunas e dos impasses existentes no projeto estratégico petista.

Manifesto na convivência entre as várias leituras marxistas e não marxistas, nas profundas críticas, mas também na sustentação de determinadas experiências comunistas, como o caso cubano, o ecletismo existente no PT tornou-se um traço negativo da sua personalidade? É possível responsabilizá-lo pelos descaminhos da construção do seu projeto socialista? Seria ele a principal expressão da impossível síntese petista, reforçando o seu caráter federativo? Nos primórdios da sua formação, uma qualidade bastante explorada que simbolizava a distinção da agremiação em relação ao monolitismo clássico das esquerdas comunistas. No final dos anos oitenta, "à esquerda" e "à direita”, a virtude transformava-se em pecado. Em vez de pluralidade, uma cacofonia: esta impressão reforça-se cada vez que a voz ruidosa de alguns grupos e tendências existentes no PT se faz ouvir mais do que a do próprio partido, produzindo uma cacofonia comprometedora ${ }^{30}$.

$\mathrm{Na}$ percepção do crítico literário soviético Mikhail Bakhtin, todo discurso está impregnado por uma multiplicidade de vozes de outros discursos. Havia uma polifonia em constante interação (STAM, 1992). Pensando a partir deste conceito, mais do que dissonâncias inaudíveis, o ecletismo petista expressava uma grande modulação de tons existentes nas esquerdas, refutando a uniformidade, garantindo uma pluralidade singular. Dessa forma, ele assumiu 
um sentido positivo, que permitiu ao partido passar pelos piores momentos da crise do socialismo real sem sofrer grandes convulsões. Paradoxalmente, ele foi viabilizado pela desagregação do mesmo.

$\mathrm{O}$ ecletismo do PT apoiava-se em alguns pontos em comum. Mas, certamente, a convivência e a sobrevivência dessa pluralidade foram garantidas a partir da unidade forjada em torno da luta antineoliberal no Brasil e no mundo, da centralidade da conquista do governo federal e da bandeira da ética na política. Contraditoriamente, nos anos noventa, a tendência predominante no partido procurou dotá-lo de um discurso e de uma atuação mais homogênea, diminuindo os canais de participação e de expressão da sua pluralidade. Nos anos subsequentes ao I Congresso, o PT não conseguiu avançar e aprofundar as estratégias do socialismo petista. Assim, equilibrando-se entre as duas grandes tradições em choque no seu interior, a comunista e a social-democrata, o processo não proporcionou uma nova síntese.

\section{ABSTRACT: THE PT AND THE CRISIS OF REAL SOCIALISM: THE CHALLENGES OF RENOVATION AND THE LEGACIES OF TRADITIONAL LEFTS}

Abstract: The article examines some aspects of the debate held by PT on the crisis of real socialism. Investigates the impact of the collapse of that experience on the different visions of socialism within the PT. The text also analyzes the dialogue and confrontation between the legacies of the Second and Third International and the "petista socialism", which made the idea of "ground zero" - the construction of a "new socialism" detached from the traditions -, the mark birth of its alternative project for society.

Keywords: PT. Socialism. Crisis. Ground Zero.

\section{Notas}

${ }^{1}$ Registrando a frase de Hamilton Pereira, Alexandre Fortes identifica na narrativa petista sobre a história brasileira a forte sensação de que "O Brasil foi descoberto em São Bernardo do Campo". FORTES, Alexandre (Org.). História e perspectivas da esquerda. São Paulo/Chapecó: Ed. FPA/Argos, 2005.

${ }^{2}$ SECRETARIA DE FORMAÇÃO POLÍTICA DO PT. Cartilha O que é o PT. São Paulo, 1991. 
${ }^{3}$ PARTIDO DOS TRABALHADORES. Boletim Nacional, $\mathrm{n}^{\circ}$ 51, 1990. p. 431-432.

${ }^{4}$ FEVEREIRO, José Luís. $1^{\circ}$ Congresso - Balanço de uma disputa. Teoria e Debate, $\mathrm{n}^{\circ} 18,30 / 07 / 1992$.

5 Teoria e Debate é uma revista do Partido dos Trabalhadores cujo primeiro número foi lançado em 1987. Antecipando-se ao período pré-congressual do PT (1991), a publicação cumpriu um importante papel de estímulo à reflexão e ao debate, ultrapassando inclusive as fronteiras partidárias. T\&D publicou divergentes concepções sobre a temática do socialismo e das estratégias para a transformação do Brasil, envolvendo assuntos como o marxismo, o socialismo, as experiências do leste europeu e da URSS, a revolução e o Estado cubano, a questão do mercado e da democracia, o papel do indivíduo no projeto revolucionário, a articulação entre socialismo e poder local.

${ }^{6}$ REIS, Daniel Aarão. Um mundo de ponta cabeça. Teoria e Debate, $n^{\circ} 8$, out./ nov./dez. 1989.

${ }^{7}$ Ibid.

${ }^{8}$ FORNAZIERI, Aldo. Limites da estratégia. Teoria e Debate, $\mathrm{n}^{\circ}$ 13, 1991.

${ }^{9}$ GARCIA, Marco Aurélio. Terceira via. A social-democracia e o PT. Teoria e Debate, $\mathrm{n}^{\circ} 12,1990$.

${ }^{10}$ GORENDER, Jacob. A revolução de outubro: revolução ou golpe de Estado? In: COGGIOLA, Osvaldo (Org.). Trotsky Hoje. São Paulo: Ensaio, 1994. p. 44. ${ }^{11}$ MULLER, Wilson. Tradição/contradição - o pior cego é que não quer ver. Teoria e Debate, $\mathrm{n}^{\circ}$ 12, 1990.

12 1917-1987. Socialismo em debate. São Paulo: Instituto Cajamar, p. 24, 1988.

${ }^{13}$ FRANCO, Augusto de. Muito o que (des)fazer. Teoria e Debate, no 9, 1990.

${ }^{14}$ TRAGTENBERG, Maurício. Reunificação Alemã. Passado que não Passa. Teoria e Debate, $\mathrm{n}^{\circ}$ 13, 1991.

${ }^{15}$ Teses sobre socialismo. Pré-Tese $\mathrm{n}^{\circ}$ 5. In: Jornal do Congresso do PT, $\mathrm{n}^{\circ} 2$, junho de 1991. p. 14.

${ }^{16}$ EDITORIAL. Duas palavras de (des)ordem. Teoria e Debate, $\mathrm{n}^{\circ}$ 1, 1987.

${ }^{17}$ CAPISTRANO FILHO, David; FAVRE, Luís. Duas maneiras de ver (e criticar) a "glasnost" e a "perestroika" soviéticas. Teoria e Debate, no 2, 1988.

${ }^{18} \mathrm{O}$ termo Nomenclatura foi amplamente empregado no jargão político até o fim dos anos oitenta para designar a emergência de uma burocracia dirigente nos países socialistas de tipo soviético, que gozavam de enormes privilégios devido à ocupação de cargos fundamentais na estrutura do Estado. Para alguns autores, esse grupo expressava a conformação de uma nova classe dominante e de um novo modo de produção em tais sociedades (FERNANDES, 2000, p. 108).

${ }^{19}$ MACHADO, João. Pela tradição marxista. Teoria e Debate, no 10, p. 15, 1990.

${ }^{20}$ AZEVEDO, Ricardo. Qual é a tua, Convergência? Entrevista Valério Arcary. Teoria e Debate, no 10, 1990. 
${ }^{21}$ AZEVEDO, Op. cit.

${ }^{22}$ CONVERGÊNCIA SOCIALISTA. Teses sobre a situação política mundial, p. 2, 1990. ${ }^{23}$ MULLER, Op. cit.

24 Ibid. O Novo Fórum era um agrupamento político que aglutinava várias forças de esquerda da antiga Alemanha Oriental. No turbulento processo que resultou na famosa queda do muro de Berlim, em 1989, eles adotaram uma plataforma de renovação do socialismo e uma postura crítica em relação à reunificação alemã. Apesar do sucesso inicial, suas proposições perderam força para grupos que defenderam um programa de reunificação e de restauração do capitalismo na RFA.

${ }^{25}$ GORENDER, Jacob. Testemunha Ocular. In: Teoria e Debate, São Paulo, no 16, out./nov./dez. 1991.

${ }^{26}$ Ver: Revolução Derruba Ditadura Stalinista. Convergência Socialista, n 305 , p. 1, 6 e 7 e Abaixo os planos de restauração de Yeltsin. Os desafios e perigos da revolução soviética. Convergência Socialista, no 306, p. 1.

${ }^{27}$ SEPPO, David. Golpe conservador, golpe liberal. Por que agora? Em Tempo. no 253, p. 9, 1991.

${ }^{28}$ GARCIA, Op. cit., 1992, no 18.

${ }^{29}$ Ibid.

${ }^{30}$ GARCIA, Op. cit., 1990, no 12, p. 38.

\section{Referências}

FERNANDES, Luís. O Enigma do socialismo real: um balanço crítico das principais teorias marxistas e ocidentais. Rio de Janeiro: Mauad, 2000.

FORTES, Alexandre (Org.). História e perspectivas da esquerda. São Paulo/Chapecó: Ed. FPA/Argos, 2005.

GORENDER, Jacob. A revolução de outubro: revolução ou golpe de Estado? In: COGGIOLA, Osvaldo (Org.). Trotsky Hoje. São Paulo: Ensaio, 1994.

REIS, Daniel Aarão. O Partido dos Trabalhadores: trajetórias, metamorfoses, perspectivas. In: FERREIRA et allii. As esquerdas no Brasil. Revolução e democracia. 1964... Vol. 3, Rio de Janeiro: Civilização Brasileira, 2007.

STAM, Robert. Bakhtin: da teoria literária à cultura de massa. São Paulo: Ática, 1992.

Recebido em: 28/10/2012.

Aprovado em: 01/07/2013. 
